\title{
Galvanic Corrosion Behaviour of Phosphate Nodular Cast Iron in Different Types of Residual Waters and Couplings
}

\author{
CARMEN NEJ NERU ${ }^{1}$, MANUELA CRISTINA PERJ U1*, DUMITRU DORU BURDUHOS NERGIS ${ }^{1}$, ANDREI VICTOR SANDU ${ }^{1,2}$, \\ COSTICA BEJ INARIU'* \\ ${ }^{1}$ Gheorghe Asachi Technical University of lasi, Faculty of Materials Science and Engineering, 67 D. Mangeron Str., 700050 Iasi, \\ Romania \\ ${ }^{2}$ Romanian Inventors Forum, 3 Sf. P. Movila Str., 700089 Iasi, Romania
}

\begin{abstract}
The aim of this paper is to analyze the corrosion process that occurs in galvanic couplings of different alloys. The study focuses on materials that can come into contact in submersible pumps used by water treatment plants. Because, the rotor, one of the pump main components must possess high chemical and mechanical properties, nodular cast iron is usually used. Therefore, this is exposed in the same environment with different types of materials, such as aluminum, copper, bronze, grey cast iron, low alloy steel or stainless steel from which other components are made. The tests have been performed in three types of residual waters with neutral, acidic and basic $\mathrm{pH}$. According to this study, the nodular cast iron galvanic corrosion resistance is highly improved by the phosphate layer deposited on its surface.
\end{abstract}

Keywords: galvanic corrosion, wastewater, nodular cast iron, phosphate layer, galvanic couple

Galvanic corrosion represents an electrochemical process in which a metal or alloy corrodes preferentially when it comes into electrical contact with a different metal or alloy forming a couple, while both materials are immersed in the same electrolyte [1]. The electrolyte represents the medium for ion migration between these two metals, one representing the anode and the other one the cathode. In this process, the metal representing the anode is corroded at a higher rate while the cathode metal corrosion rate decreases, sometimes even up to suppression. In general, the corrosion reactions that occur are similar to those that take place when the respective metals are uncoupled, but the corrosion rate of the higher electronegative metal is increased, sometimes up to dramatic changes [2].

Therefore, when the nodular iron is corroded in an electrolytic environment two processes take place simultaneously: the dissolution of iron at the anode ( $\mathrm{Fe} \rightarrow$ $\left.\mathrm{Fe}^{2+}+2 \mathrm{e}^{-}\right)$and a reduction process at the cathode. In alkaline or neutral environments at the cathode, the reduction of oxygen dissolute in the solution takes place $\left(\mathrm{O}_{2}+2 \mathrm{H}_{2} \mathrm{O}+4 \mathrm{e}^{-} \rightarrow 4 \mathrm{OH}^{-}\right)$, while in an acidic environment the reduction of hydrogen ions $\left(2 \mathrm{H}^{+}+2 \mathrm{e}^{-} \rightarrow \mathrm{H}_{2}\right)$ takes place [3]. In the case of uncoupled corrosion, the anodic and cathodic reactions take place in small areas on the metal surface, while in the bimetallic corrosion the cathodic reaction takes place entirely on the higher electropositive alloy of the couple, while the anodic reaction appears on the higher electronegative component of the couple.

Appreciable galvanic corrosion process can be obtained only when the corrosion potentials of the coupled metals are sufficiently different. The castiron and the nodular castiron, in particular, have quite large negative electrode potentials so thatin any galvanic series these are located between the most electronegative metals, lower than these being only aluminum alloys, zinc or magnesium. On this basis, itcan be appreciated that the nodular cast iron in coupling with many metals or alloys will function as an anode and will undergo an advanced corrosion process [4]. However, the difference between the corrosion potentials is not a sufficient criterion to predict a certain degree of galvanic corrosion, this difference expresses only the thermodynamic probability of the occurrence of the galvanic corrosion butitdoes nothighlight anything about the kinetics of the process, meaning the corrosion rate [5, 11-24].

The severity of bimetallic corrosion depends on several factors that can influence the reaction rate, such as temperature, electrolyte composition, $\mathrm{pH}$, the ratio of the areas of the two metals of the couple etc. [6].

The area report is very important regarding the probability of producing bimetallic corrosion; a much larger surface area of the cathode than that of the anode allows a higher amount of oxygen to be reduced, higher galvanic current and consequently a higher corrosion rate [7-9]. For a constant cathode area, the corrosion intensity increases with the decrease of the anode area. When the anode area is much larger than the cathode area the coupling effect is insignificant, while the couple current is very low [10].

The $\mathrm{pH}$ value can influence the galvanic corrosion due to it's on influences the cathode process.

In this paper, different aspects regarding the influence of $\mathrm{pH}$ and the surface ratio on the galvanic corrosion parameters have been analyzed.

\section{Experimental part}

The nodular cast iron and the phosphate nodular cast iron were coupled with a series of alloys that could come into contact in wastewater circulation installations. The elemental chemical compositions of the studied alloys, presented in Table 1, were determined by optical emission spectroscopy by means of a Foundry-Master spectrometer (WAS Company).

The phosphate nodular cast iron (PNCI) sample was obtained by immersion in aqueous acidic solutions in three stages: degreasing, chemical pickling and phosphating itself, according to the procedures described previously [1, 24-27].

In this study different corrosive mediums have been utilized. Table 2 presents the base chemical composition of DW 1 synthetic wastewater. In these, the inorganic components are responsible for the corrosive properties of the solution, while the food components can act as

\footnotetext{
* email: mcperju@tuiasi.ro; costica.bejinariu@tuiasi.ro
} 
Table 1

CHEMICAL COMPOSITION OF STUDIED ALLOYS

\begin{tabular}{|c|c|c|}
\hline Alloy & Abbreviation & Chemical composition, \% \\
\hline Nodular cast iron & $\mathrm{NCI}$ & $\begin{array}{l}\mathrm{Fe}-78.1 ; \mathrm{C}-4.5 ; \mathrm{Si}-2.28 ; \mathrm{Ni}-0.12 ; \mathrm{W}-2.29 ; \mathrm{P}-0.05: \mathrm{Cr}-0.02 ; \mathrm{Pb}-0.350 ; \mathrm{Mo}- \\
0.200 ; \mathrm{Mn}-0.09 ; \mathrm{S}-0.150\end{array}$ \\
\hline Grey cast iron & $\mathrm{CI}$ & Fe-92.78; C-3.97: S-2.87: Mn-0.25; P-0.06; S-0.07: other-1.02 \\
\hline Low-alloy steel & LAS & Fe-98.50; C-0.26; Si-0.11; Mn-0.42; P-0.02; S-0.08; Cr-0.09; Cu-0.325 \\
\hline Bronze & $\mathrm{B}$ & $\mathrm{Cu}-85.62 ; \mathrm{Sn}-11.2 ; \mathrm{Pb} 1.0 ; \mathrm{Zn}-1.39 ;$ other- 0.79 \\
\hline Brass & $\mathrm{Br}$ & $\mathrm{Cu}-58.4 ; \mathrm{Zn}-39.4 ; \mathrm{Pb}-1.60 ; \mathrm{Sn}-0.08 ; \mathrm{Fe}-0.11 ; \mathrm{Ni}-0.12$ \\
\hline Stainless steel & SS & $\begin{array}{l}\text { Fe-84.80; Cr- } 13.1 ; \mathrm{Ni}-0.43 ; \mathrm{Ti}-0.02 ; \mathrm{C}-0.441 ; \mathrm{Si}-0.522 ; \mathrm{Mn}-0.37 ; \mathrm{Mo}- \\
0.05 ;\end{array}$ \\
\hline
\end{tabular}

Table 2

CHEMICAL COMPOSITION OF DW1 SYNTHETIC RESIDUAL WATER.

\begin{tabular}{|l|c|c|c|c|c|}
\hline \multicolumn{1}{|c|}{ Inorganic components } & $\mathrm{mg} / \mathrm{l}$ & Food components & $\mathrm{mg} / \mathrm{l}$ & Metallic compounds & $\mathrm{mg}$ metal/ \\
\hline $\mathrm{NH}_{4} \mathrm{Cl}$ & 15 & Powder milk & 118 & $\mathrm{Cr}\left(\mathrm{NO}_{3}\right)_{3} .9 \mathrm{H}_{2} \mathrm{O}$ & 0.10 \\
\hline $\mathrm{CH}_{3} \mathrm{COONa} .3 \mathrm{H}_{2} \mathrm{O}$ & 142 & Ale yeast & 54 & $\mathrm{CuCl}_{2} .2 \mathrm{H}_{2} \mathrm{O}$ & 0.20 \\
\hline $\mathrm{MgSO}_{4} .7 \mathrm{H}_{2} \mathrm{O}$ & 32 & Starch & 122 & $\mathrm{MnCl}_{2}$ & 0.05 \\
\hline $\mathrm{CaHPO}_{4}$ & 20 & Soybean oil & 15 & $\mathrm{NiSO}_{4} .7 \mathrm{H}_{2} \mathrm{O}$ & 0.08 \\
\hline $\mathrm{K}_{2} \mathrm{HPO}_{4.3 \mathrm{H}_{2} \mathrm{O}}$ & 56 & & & $\mathrm{PbCl}_{2}$ & 0.07 \\
\hline $\mathrm{FeSO}_{4} .7 \mathrm{H} 2 \mathrm{O}$ & 14 & & & & \\
\hline Urea & 98 & & & & \\
\hline
\end{tabular}

protectors or inhibitors. The DW 1 solution has an approximatively neutral $\mathrm{pH}$ of 6.5 .

To study the influence of solution $\mathrm{pH}$ on the corrosion behavior, the $\mathrm{pH}$ of the DW 1 solution has been changed by titrating $1 \mathrm{~N}$ hydrochloric acid or $1 \mathrm{~N}$ sodium hydroxide, respectively. Therefore, two more solution has been obtained:

Solution DW2 with a $p H$ of 3.0 through titrating $0.1 \mathrm{~N} \mathrm{HCl}$ solution in the base solution (DW1).

Solution DW3 with a pH of 11.0 through titrating $0.1 \mathrm{~N}$ $\mathrm{NaOH}$ solution in the base solution (DW1).
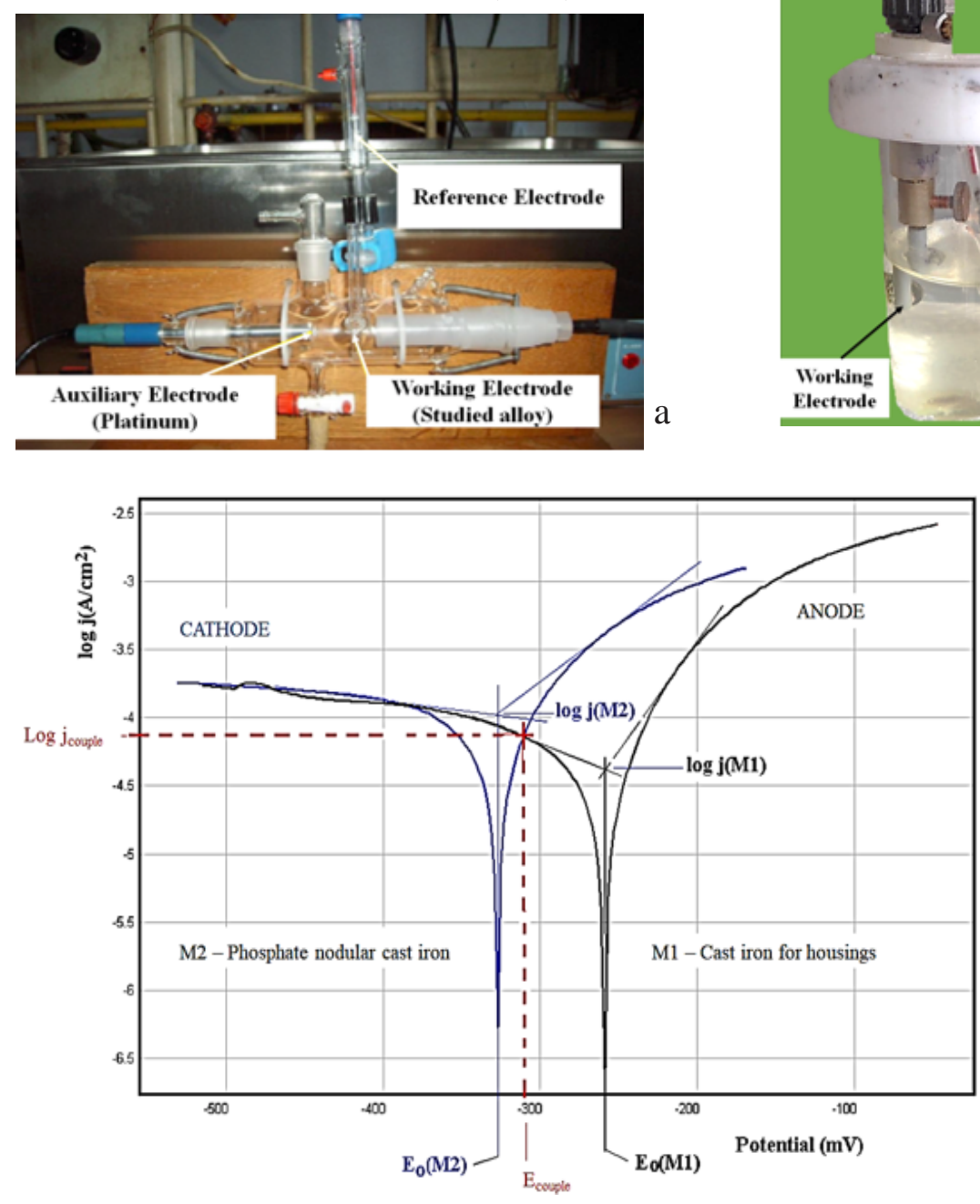

A VoltaLab 21 (PGP 201) (Radiometer Analytical SAS France) potentiometer was used to determine the parameters of the galvanic corrosion, respectively $\mathrm{E}_{\text {coune }}$ the couple potential and $J_{\text {couple }}$ - the density of the couple, while for experimental data acquisition and processing the VoltaMaster 4 software was used.

The galvanic corrosion parameters evaluation has been realized by the Evans method [4] and Tafel extrapolation $[5,6]$. Therefore, linear polarization curves obtained separately for each alloy were studied in the same corrosion environments and under the same boundary conditions

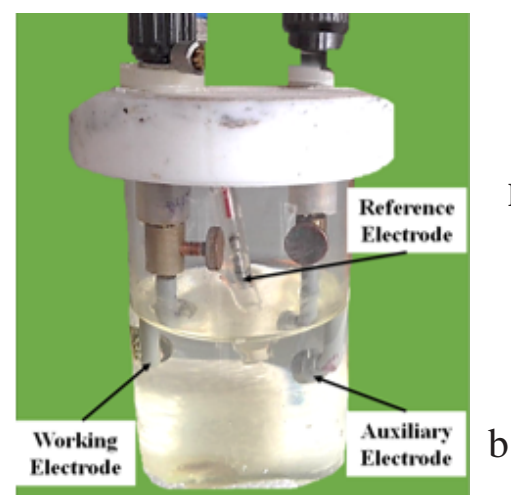

Fig. 1. Types of cells with three electrodes: a) for small surface; b) for large surface.
Fig. 2. Example of Tafel curves plotted in Evans diagram (Phosphate nodular cast iron -grey cast iron couple in DW2 solution) 
(temperature, aeration, potential scanning rate). The measurements were realized in two types of cells with three electrodes. Fig. 1.a) presents the cell used for polarization curves of small surface samples $\left(0.283 \mathrm{~cm}^{2}\right)$, and Fig. 1.b) presents the one used for large surface samples $\left(2.85 \mathrm{~cm}^{2}\right)$.

The polarization curves are represented in the Evans diagram as the logarithm of the current density depending on the electrode potential. Based on the theory of the mixed potential the Tafel slopes are plotted for both alloys were the anodic and cathodic branches intersection can be observed. The Evans coordinates of the intersection of the Tafel slopes give the values for the couple potential $\left(\mathrm{E}_{\text {coupls }}\right)$ and the current density $(J$ couple $)$, as represented in figure 2 .

To evaluate the galvanic corrosion parameters $\left(\mathrm{E}_{\text {coupde' }}\right.$ $\left.j_{\text {a }}\right)$, the polarization curves for both metals are plotted in Evans diagram (logj; E). The noble metal (M1) is the one that has a higher positive corrosion potential and a lower corrosion rate when it is exposed to the same environmental conditions when it is coupled. The less noble metal (M2) has a higher negative corrosion potential and a higher corrosion rate (up to M1) when it is uncoupled. The intersection coordinates of the cathode branch of the noble metal with the anodic branch of the less noble metal represent the values for $E_{\text {couple }}$ and $j_{\text {couple }}$. The potential of the noble metal is reduced from the uncoupled value $E_{\text {cor }}(\mathrm{M} 1)$ to the Ecouple, thus leading to a lower dissolution of the material. The corrosion potential of the higher active metal is increased from the uncoupled value $E_{\text {cor }}(M 2)$ to higher positive values (up to the Ecouple), thereby increasing the dissolution rate [12].

\section{Results and discussions}

The corrosion potentials for nodular castiron, phosphate nodular castiron and differenttypes of alloys used in couples which were evaluated through the Evans method are presented in Table 3.

According to the data from Table 3 despite the type of the corrosive environment, when coupling the nodular cast iron with other alloys, these are the most active alloys by being the anode, while another alloy becomes the cathode. However, there are two exceptions when coupled with grey cast iron in DW 1 and in case of grey cast iron-low alloy steel couple in the DW2 (Fig. 3).

Tables 4, 5 and 6 present the results obtained by coupling the nodular cast iron with a series of alloys in synthetic, neutral, acidic and basic wastewaters.

In the case of the quasi-neutral wastewaters, i.e. DW 1 solution, the couple current decreases with the increase of the cathode/anode surface instead of increasing [8], but, on the contrary, for all couples, the increase of this ratio caused the reduction of the current density.

Contrary to expectations, in acid corrosion environment, i.e. DW2 solution, by coupling the nodular castings with higher noble alloys (stainless steel, bronze and brass), a ten times larger surface of the noble alloy than the surface of the nodular castiron leads to a decrease of couple current

\begin{tabular}{|l|c|c|c|}
\hline \multirow{2}{*}{ Alloy } & \multicolumn{3}{c|}{ Eor $_{\text {cor }}$ DV/ESC) } \\
\cline { 2 - 4 } & DW1 & DW2 & DW3 \\
\hline Nodular cast iron (NCI) & -627 & -643 & -343 \\
\hline Phosphate nodular cast iron (PNCI) & -581 & -618 & -327 \\
\hline Stainless steel(SS) & -312 & -318 & +308 \\
\hline Bronze (B) & -52 & -117 & -65 \\
\hline Brass (Br) & -48 & -80 & -4 \\
\hline Low-alloy steel (LAS) & -534 & -618 & -112 \\
\hline Grey cast iron (CI) & -606 & -642 & -259 \\
\hline
\end{tabular}

Table 3

CORROSION POTENTIAL OF COUPLED ALLOYS IN THREE TYPES OF WASTEWATER

\begin{tabular}{|c|c|c|c|c|c|}
\hline COUPLE & $\mathrm{S}_{\text {cathode }} / \mathrm{S}_{\text {mode }}$ & $\begin{array}{l}E_{\text {eouplu }} \\
{[\mathrm{mV}]}\end{array}$ & $\begin{array}{c}\log \mathrm{j} \\
\left(\mathrm{A} / \mathrm{cm}^{2}\right)\end{array}$ & $\begin{array}{l}10^{6} \cdot \mathrm{j} \text { couphe } \\
{\left[\mathrm{A} / \mathrm{cm}^{2}\right]}\end{array}$ & $\begin{array}{c}\text { josuph } \\
{\left[\mu \mathrm{A} / \mathrm{cm}^{2}\right]}\end{array}$ \\
\hline \multirow{2}{*}{$\mathrm{NCI} / \mathrm{SS}$} & 1 & -586 & -3.575 & 266.07 & 266 \\
\hline & 10 & -587 & -4.293 & 50.9 & 50.9 \\
\hline \multirow{2}{*}{$\mathrm{NCI} / \mathrm{B}$} & 1 & -576 & -3.649 & 224.39 & 224 \\
\hline & 10 & -425 & -3.668 & 214.8 & 215 \\
\hline \multirow{2}{*}{$\mathrm{NCI} / \mathrm{Br}$} & 1 & -582 & -3.679 & 209.4 & 209 \\
\hline & 10 & -403 & -3.696 & 201.4 & 201 \\
\hline \multirow{2}{*}{ NCI/LAS } & 1 & -577 & -3.903 & 125.02 & 125 \\
\hline & 10 & -555 & -4.163 & 68.70 & 68.7 \\
\hline \multirow{2}{*}{$\mathrm{NCI} / \mathrm{CI}$} & 1 & -616 & -4.382 & 41.50 & 41.5 \\
\hline & 10 & -614 & -4.457 & 34.91 & 34.9 \\
\hline \multirow{2}{*}{ NCI/PNCI } & 1 & -608 & -4.092 & 80.909 & 80.9 \\
\hline & 10 & -595 & -4.334 & 46.34 & 46.34 \\
\hline
\end{tabular}

Table 4 INFLUENCE OF THE CATHODE/ ANODE SURFACE RATIO ON THE GALVANIC CORROSION PARAMETERS OF NODULAR CAST IRON IN DW 1

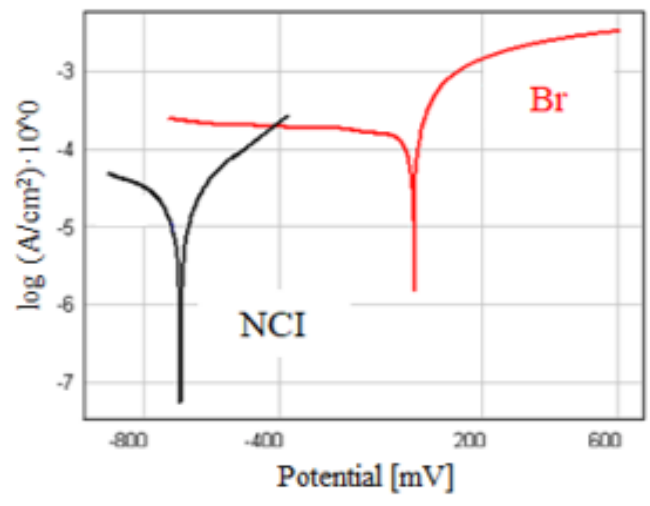

REV.CHIM.(Bucharest) $\$ 70 \diamond$ No. $10 \diamond 2019$

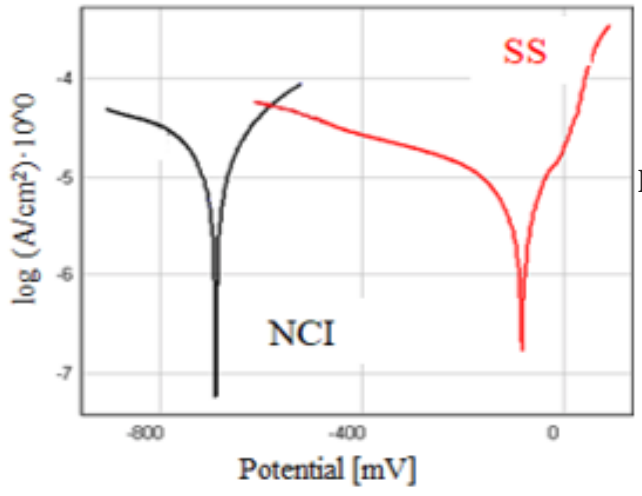

Fig. 3. Evans diagrams of galvanic couples in DW 1: a) Nodular cast iron -brass ( $\mathrm{NCl}-\mathrm{Br}$ ) couple; b) Nodular cast iron stainless steel ( $\mathrm{NCl}-\mathrm{SS})$ couple. 


\begin{tabular}{|c|c|c|c|c|c|c|}
\hline COUPLE & $\mathrm{S}_{\text {cachode }} / \mathrm{S}_{\text {atode }}$ & $\begin{array}{l}\text { Ecopplu } \\
\text { [mV] }\end{array}$ & $\begin{array}{c}\log j \\
\left(\mathrm{~A} / \mathrm{cm}^{2}\right)\end{array}$ & $\begin{array}{l}10^{6} . j \text { jouphen } \\
{\left[\mathrm{A} / \mathrm{cm}^{2}\right]}\end{array}$ & $\begin{array}{c}\text { jecosplu } \\
{\left[\mu \mathrm{A} / \mathrm{cm}^{2}\right]}\end{array}$ & \multirow{13}{*}{$\begin{array}{c}\text { Table } 5 \\
\text { INFLUENCE OF } \\
\text { THE CATHODE/ } \\
\text { ANODE SURFACE } \\
\text { RATIO ON THE } \\
\text { GALVANIC } \\
\text { CORROSION } \\
\text { PARAMETERS OF } \\
\text { NODULAR CAST } \\
\text { IRON IN DW2 }\end{array}$} \\
\hline \multirow{2}{*}{ NCI/SS } & 1 & -596 & -3.547 & 283.79 & 284 & \\
\hline & 10 & -492 & -3.653 & 222.3 & 222 & \\
\hline \multirow{2}{*}{$\mathrm{NCI} / \mathrm{B}$} & 1 & -423 & -2.710 & 1949.8 & 1950 & \\
\hline & 10 & -483 & -3.570 & 269.2 & 269 & \\
\hline \multirow{2}{*}{$\mathrm{NCI} / \mathrm{Br}$} & 1 & -420 & 2.710 & 1949.8 & 1950 & \\
\hline & 10 & -293 & -2.723 & 1892 & 1892 & \\
\hline \multirow{2}{*}{ NCI/LAS } & 1 & -630 & -4.165 & 68.39 & 68.4 & \\
\hline & 10 & -587 & -3.779 & 166.3 & 166 & \\
\hline \multirow{2}{*}{$\mathrm{NCI} / \mathrm{CI}$} & 1 & \multicolumn{4}{|c|}{ Curves overlapping } & \\
\hline & 10 & -609 & -3.619 & 240.4 & 240 & \\
\hline \multirow{2}{*}{ NCI/PNCI } & 1 & -631 & -4.157 & 69.663 & 69.7 & \\
\hline & 10 & -592 & -3.739 & 182.4 & 182 & \\
\hline
\end{tabular}
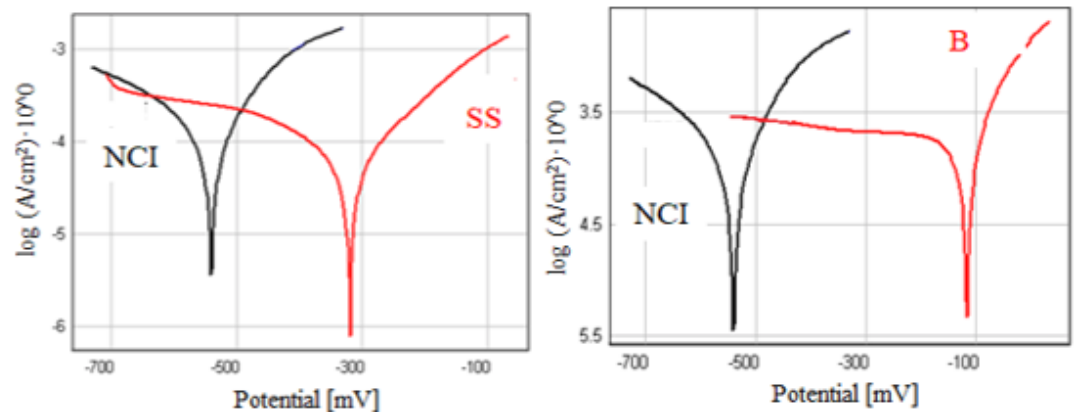

Fig. 4. Evans diagrams of galvanic couples in

DW2: a) Nodular cast iron -stainless steel (NCl-SS) couple; b) Nodular cast iron -bronze (NCl-B) couple

\begin{tabular}{|c|c|c|c|c|c|}
\hline COUPLE & $\mathrm{S}_{\text {cathode }} / \mathrm{S}_{\mathbf{a z o d e}}$ & $\begin{array}{c}E_{\text {couplu }} \\
{[\mathrm{mV}]}\end{array}$ & $\log \mathrm{j}\left(\mathrm{A} / \mathrm{cm}^{2}\right)$ & $\begin{array}{r}10^{8} \cdot \mathrm{j} \text { couph } \\
{\left[\mathrm{A} / \mathrm{cm}^{2}\right]}\end{array}$ & $\begin{array}{c}\text { josspoplu } \\
{\left[\mu \mathrm{A} / \mathrm{cm}^{2}\right]}\end{array}$ \\
\hline \multirow{2}{*}{ NCI/SS } & 1 & -281 & -3.703 & 198.15 & 198.2 \\
\hline & 10 & -604 & -3.639 & 229.6 & 230 \\
\hline \multirow{2}{*}{ NCl/B } & 1 & -392 & -4.521 & 30.13 & 30.1 \\
\hline & 10 & -650 & -4.730 & 18.61 & 18.6 \\
\hline \multirow{2}{*}{$\mathrm{NCl} / \mathrm{Br}$} & 1 & -327 & -4.443 & 36.05 & 36.0 \\
\hline & 10 & -610 & -3.732 & 185.4 & 185 \\
\hline \multirow{2}{*}{ NCILAS } & 1 & -332 & -4.369 & 42.76 & 42.8 \\
\hline & 10 & -623 & -3.879 & 132.12 & 132 \\
\hline \multirow{2}{*}{$\mathrm{NCI} / \mathrm{CI}$} & 1 & -314 & -4.119 & 76.03 & 76.0 \\
\hline & 10 & -570 & -3.408 & 391 & 391 \\
\hline \multirow{2}{*}{ NCLPNCI } & 1 & -333 & -4.626 & 23.659 & 23.7 \\
\hline & 10 & -475 & -3.753 & 176.6 & 177 \\
\hline
\end{tabular}

Table 6

INFLUENCE OF THE CATHODE/ANODE SURFACE RATIO ON THE GALVANIC CORROSION PARAMETERS OF NODULAR CAST IRON IN DW3.
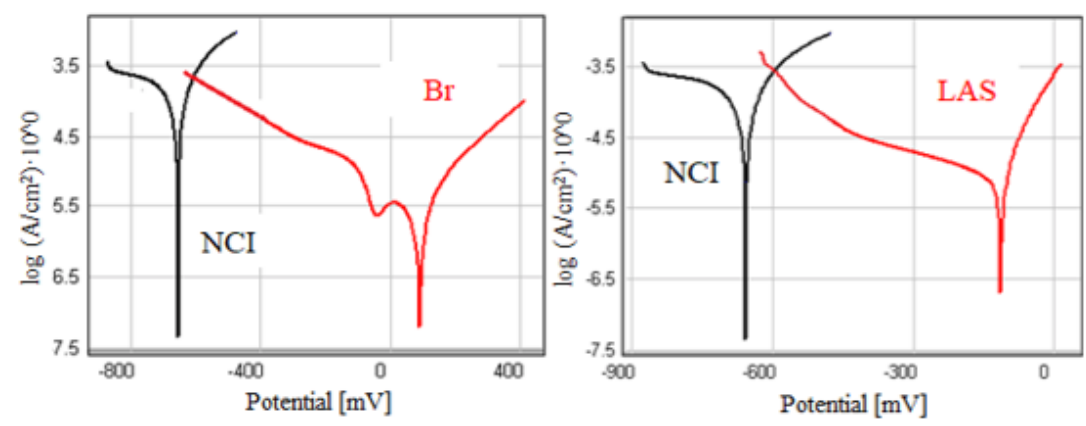

Fig. 5. Evans diagrams of galvanic couples in DW 3: a) Nodular cast iron -Brass ( $\mathrm{NCl}-\mathrm{Br}$ ) couple; b) Nodular cast iron -low-alloy steel (NCl-LAS) couple.

\begin{tabular}{|c|c|c|c|c|c|}
\hline COUPLE & $\mathrm{S}_{\text {cathode }} / \mathrm{S}_{\text {mode }}$ & $\begin{array}{l}E_{\text {couple }} \\
{[\mathrm{mV}]}\end{array}$ & $\begin{array}{c}\log \mathrm{j} \\
\left(\mathrm{A} / \mathrm{cm}^{2}\right)\end{array}$ & $\begin{array}{l}10^{6} . \text { jeoupla } \\
{\left[\mathrm{A} / \mathrm{cm}^{2}\right]}\end{array}$ & $\begin{array}{c}\text { josuphu } \\
{\left[\mu \mathrm{A} / \mathrm{cm}^{2}\right]}\end{array}$ \\
\hline \multirow{2}{*}{ PNCI/SS } & 1 & -523 & -3.622 & 2178 & 217 \\
\hline & 10 & -557 & -4.175 & 68 & 66.8 \\
\hline \multirow{2}{*}{$\mathrm{PNCL} / \mathrm{B}$} & 1 & -526 & -3.660 & 218.8 & 219 \\
\hline & 10 & -432 & 3.675 & 211.1 & 211 \\
\hline \multirow{2}{*}{$\mathrm{PNCL} / \mathrm{Br}$} & 1 & -528 & -3.685 & 206.5 & 265 \\
\hline & 10 & -437 & -3.693 & 202.76 & 203 \\
\hline \multirow{2}{*}{ PNCILAS } & 1 & -560 & -4.094 & 80.54 & 80.5 \\
\hline & 10 & -553 & -4.173 & 67.14 & 67.1 \\
\hline \multirow{2}{*}{$\mathrm{PNCI} / \mathrm{CI}$} & 1 & -595 & -4.306 & 49.43 & 49.4 \\
\hline & 10 & -609 & -4.854 & 14.00 & 14.0 \\
\hline \multirow{2}{*}{ PNCINCI } & 1 & -608 & -4.092 & 80.909 & 80.9 \\
\hline & 10 & -608 & \multicolumn{3}{|c|}{ Curves overlapping } \\
\hline
\end{tabular}

Table 7

INFLUENCE OF THE CATHODE/ANODE SURFACE RATIO ON THE GALVANIC CORROSION PARAMETERS OF PHOSPHATE NODULAR CAST IRON IN DW 1. 

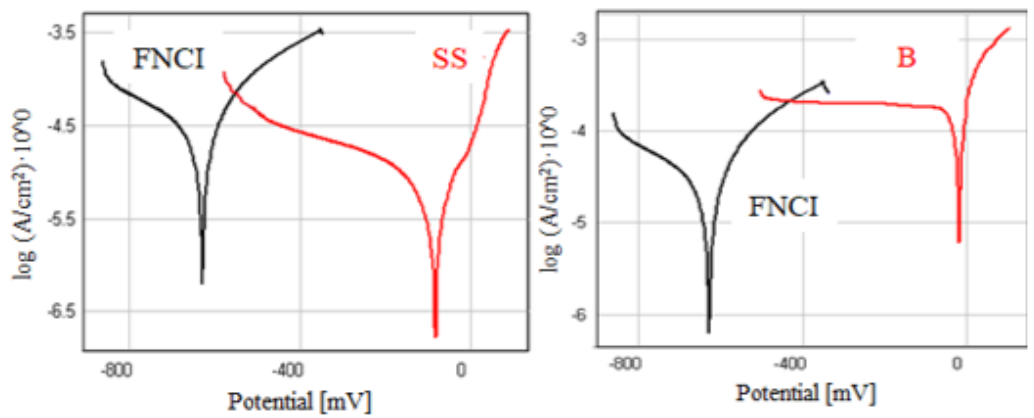

Fig. 6. Evans diagrams of galvanic couples in DW 1: a) Phosphate nodular cast iron - stainless steel (PNClSS) couple; b) Phosphate nodular cast iron - bronze (PNCl-B) couple

\begin{tabular}{|c|c|c|c|c|c|}
\hline COUPLE & $\mathrm{S}_{\text {cathoded }} / \mathrm{S}_{\text {zmode }}$ & $\begin{array}{l}E_{\text {couphlu }} \\
{[\mathrm{mV}]}\end{array}$ & $\begin{array}{c}\log \mathrm{j} \\
\left(\mathrm{A} / \mathrm{cm}^{2}\right)\end{array}$ & $\begin{array}{l}10^{6} \cdot \mathrm{j} \text { cosplu } \\
{\left[\mathrm{A} / \mathrm{cm}^{2}\right]}\end{array}$ & $\begin{array}{c}\text { jeouplu } \\
{\left[\mu \mathrm{A} / \mathrm{cm}^{2}\right]}\end{array}$ \\
\hline \multirow{2}{*}{$\mathrm{PNCI} / \mathrm{SS}$} & 1 & -58 & -3.562 & 274.2 & 274 \\
\hline & 10 & -553 & -3.586 & 259.4 & 259 \\
\hline \multirow{2}{*}{ PNCI/B } & 1 & -435 & -2.716 & 1923.1 & 1923 \\
\hline & 10 & -537 & -3.480 & 331.1 & 331 \\
\hline \multirow{2}{*}{$\mathrm{PNCI} / \mathrm{Br}$} & 1 & -435 & -2.716 & 1923.1 & 1923 \\
\hline & 10 & -548 & -3.457 & 349.1 & 349 \\
\hline \multirow{2}{*}{ PNCI/LAS } & 1 & -618 & \multicolumn{3}{|c|}{ Curves overlapping } \\
\hline & 10 & -612 & -4.508 & 31.04 & 31.0 \\
\hline \multirow{2}{*}{$\mathrm{PNCI} / \mathrm{CI}$} & 1 & -618 & \multicolumn{3}{|c|}{ Curves overlapping } \\
\hline & 10 & -627 & -4.048 & 89.54 & 89.5 \\
\hline \multirow{2}{*}{$\mathrm{PNCI} / \mathrm{NCI}$} & 1 & -631 & -4.157 & 69.66 & 69.7 \\
\hline & 10 & -627 & -4.035 & 92.26 & 92.3 \\
\hline
\end{tabular}

Table 8

INFLUENCE OF THE CATHODE/ ANODE SURFACE RATIO ON THE GALVANIC CORROSION PARAMETERS OF PHOSPHATE NODULAR CAST IRON IN DW2
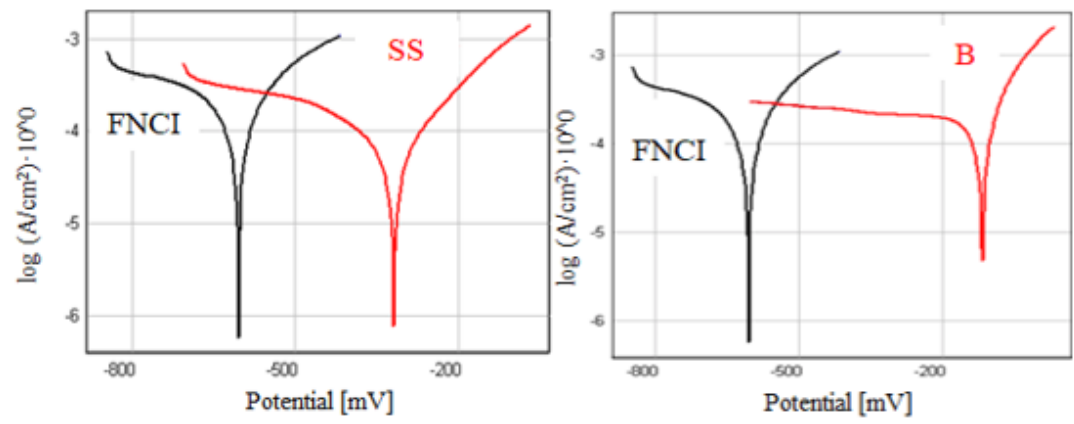

Fig. 7. Evans diagrams of galvanic couples in DW2: a) Phosphate nodular cast iron - stainless steel (PNCl-SS) couple; b) Phosphate nodular cast iron - bronze (PNCl-B) couple density, this decrease being drastic in case of the $\mathrm{NCl}-\mathrm{B}$ couple. In the case of $\mathrm{NCl}-\mathrm{LAS}, \mathrm{NCl}-\mathrm{Cl}$ and $\mathrm{NCl}-\mathrm{FNCl}$ at a $\mathrm{S}_{\text {catod }} / \mathrm{S}_{\text {nnod }}$ ratio of 10 the density of the couple current increases between 3 and 8 times (Fig. 4).

In the alkaline environment, i.e. DW 3 solution, in the case of all couples, except the $\mathrm{NCl}-\mathrm{Br}$ couple, the couple current increases as the ratio between surfaces increases (Fig. 5).

Figure 6 presents the Evans diagrams of the couplings between phosphate nodular cast iron-steel and nodular phosphate cast iron-bronze
In the case of coupling the phosphate nodular iron with the same alloys the behavior is similar. For example, in DW 1, the increase of the cathode surface decreases the density of the couple current, while in DW2, in the couplings with noble alloys the couple current decreases, also by coupling with less noble alloys the couple currentincreases (Fig. 7).

However, in the alkaline corrosive environment, the rule of increasing the density of the couple current with the $\mathrm{S}_{\text {catod }} / \mathrm{S}_{\text {anod }}$ ratio is respected (Fig. 8).

\begin{tabular}{|c|c|c|c|c|c|}
\hline COUPLE & $\mathrm{S}_{\text {carthode }} / \mathrm{S}_{\text {anode }}$ & $\begin{array}{l}\text { E Eowph } \\
{[\mathrm{mV}]}\end{array}$ & $\log j\left(A / \mathrm{cm}^{2}\right)$ & $\begin{array}{l}10^{6} . \text { jeouples } \\
{\left[\mathrm{A} / \mathrm{cm}^{2}\right]}\end{array}$ & $\begin{array}{c}\text { joosphy } \\
{\left[\mu \mathrm{A} / \mathrm{cm}^{2}\right]}\end{array}$ \\
\hline \multirow{2}{*}{ PNCL/SS } & 1 & -288 & -3.701 & 199.06 & 199 \\
\hline & 10 & -466 & -3.681 & 208.4 & 208 \\
\hline \multirow{2}{*}{ PNCI/B } & 1 & -319 & -4.535 & 29.17 & 29.2 \\
\hline & 10 & -518 & -4.264 & 54.45 & 54.45 \\
\hline \multirow{2}{*}{$\mathrm{PNCL} / \mathrm{Br}$} & 1 & -318 & -4.473 & 33.65 & 33.7 \\
\hline & 10 & -491 & -3.863 & 137.1 & 137 \\
\hline \multirow{2}{*}{ PNCI/LAS } & 1 & -319 & -4.660 & 21.89 & 21.9 \\
\hline & 10 & -483 & -3.800 & 158.5 & 159 \\
\hline \multirow{2}{*}{$\mathrm{PNCI} / \mathrm{CI}$} & 1 & -319 & -4.129 & 74.3 & 74.3 \\
\hline & 10 & -477 & -3.747 & 179.1 & 179 \\
\hline \multirow{2}{*}{ PNCI/NCI } & 1 & -333 & -4.626 & 23.66 & 23.7 \\
\hline & 10 & -475 & -3.753 & 176.6 & 177 \\
\hline
\end{tabular}

Table 9

INFLUENCE OF THE CATHODE/ANODE SURFACE RATIO ON THE GALVANIC CORROSION PARAMETERS OF PHOSPHATE NODULAR CAST IRON IN DW3 

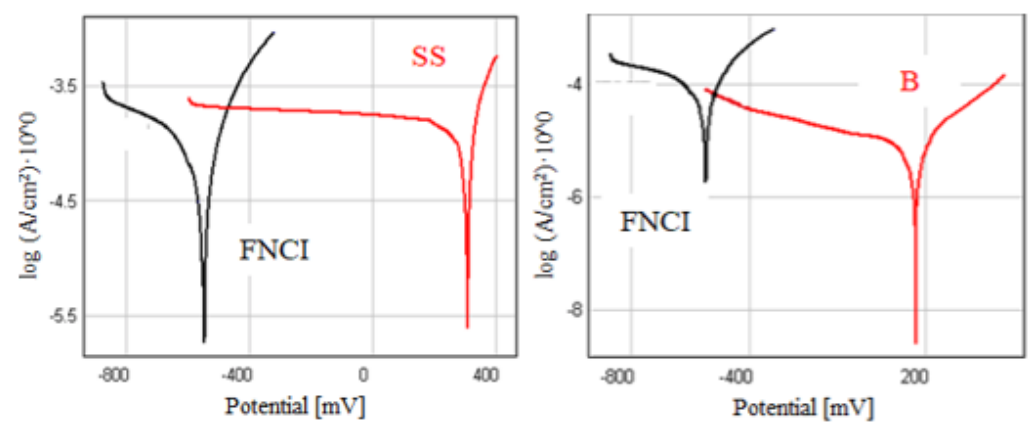

Fig. 8. Evans diagrams of galvanic couples in DW3: a) Phosphate nodular cast iron -stainless steel (PNCI-SS) couple; b) Phosphate nodular cast iron -bronze (PNCI-B) couple
The experiments were performed in accordance with the occupational health and safety laws and regulations in order to eliminate all the risks and dangers which can affect the human resource during the experiment procedures [25-29].

\section{Conclusions}

According to Evans diagrams in all the couples analyzed nodular cast iron, grey cast iron, and phosphate nodular cast iron represent the corroded (less noble) alloys.

In the case of phosphate nodular cast iron - grey cast iron couple and phosphate nodular cast iron - untreated nodular cast iron couple, the noble alloy is phosphate nodular cast iron, which justifies the phosphating treatment in terms of corrosion resistance. This aspect can be observed for all types of neutral, acid and basic wastewater.

The most unfavorable couplings for both nodular and phosphate nodular castiron in wastewaters are these with bronze, brass or stainless steel.

In basic solutions, the couple with the maximum couple current density is phosphate and nonphosphate cast iron with stainless steel. While in acid waters, the couple with the maximum couple current density is that of phosphate and nonphosphate nodular cast iron with bronze or brass.

\section{References}

1.SANDU, A.V., CODDET, C., BEJ INARIU, C., Rev. Chim. (Bucharest), 63, no. 4, 2012, p. 401.

2.J AMAL, A., QASIM, A., Al-Khawarizmi Engineering J ournal, 5, 2009, pp. 60.

3.BURDUHOS-NERGIS, D.P., NEJNERU, C., BURDUHOS-NERGIS, D.D., SAVIN, C., SANDU, A.V., TOMA, S.L., BEJINARIU, C., Rev. Chim. (Bucharest), 70, no. 1, 2019, p. 215.

4.SANDU, A.V., CODDET, C., BEJ INARIU, C., J ournal of Optoelectronics and Advanced Materials, 14, no. 7-8, 2012, p. 699.

5.EVANS, U.R., An Introduction to Metallic Corrosion, 2nd ed. London: Arnold, 1972

6.KELLY, R.G., SCULLY, R., SHOESMITH, D.W., BUCHHEIT, R.G., Electrochemical Techniques in Corrosion Science and Engineering, New York: Marcel Dekker Inc, 2003

7.MARCUS, P., Corrosion Mechanisms in theory and practice, New York: Marcel Dekker Inc., 2002

8.STONE, C., GLASS, G., ROBERTS, A., DAVISON, N., MATEC Web of Conferences, 289, 2019, 03012.

9.PIEROZYNSKI, B., PIOTROWSKA, G., Water, 10, 2019, p. 770.

10.ZIEGENHAGEN, R., RECLARU, L., ARDELEAN, L., GRECU, A., Materials, 12, 2019, p. 1.
11.HAIFENG, Z., IOP Conference Series: Earth and Environmental Science, 252, 2019, 022015.

12.MORIMOTO, T., J ournal of the Japan Welding Society, 87, 2018, pp. 62.

13.ROCKEL, B., SCHEDLITZKY, M., BENDER, D., ROMAN, D., Galvanic corrosion (contact corrosion), Corrosion Handbook, 2008, DECHEMA e.V., Society for Chemical Engineering and Biotechnology, doi:10.1002/ 9783527610433.chb07104

14.KUHN, J. R., Industrial \& Engineering Chemistry, 22, 2002, doi:10.1021/ie50244a008

15.FLOREA, C.D., CARCEA, I., CIMPOESU, R., TOMA, S.L., SANDU, I.G., BEJ INARIU, C., Rev. Chim.(Bucharest), 68, no. 10, 2017, pp. 2397. 16.FLOREA, C.D., MUNTEANU, C., CIMPOESU, N., SANDU, I.G., BACIU, C., BEJ INARIU, C., Rev. Chim. (Bucharest), 68, no. 11, 2017, pp. 2582. 17.MINCIUNA, M.G., VIZUREANU, P., ACHITEI, D.C., GHIBAN, B., SANDU, A.V., MARECI, D., BALAN, A., Rev. Chim. (Bucharest), 65, no. 11,2014, p. 1138.

18.BALTATU, S., VIZUREANU, P., MARECI, D., BURTAN, L.C., CHIRUTA, C., TRINCA, L.C., Materials And Corrosion-Werkstoffe Und Korrosion, 67, no. 12, 2016, p. 1314.

19.NEJ NERU, C., CIMPOESU, N., STANCIU, S., VIZUREANU, P., SANDU, A.V., Metalurgia International, 14, no. 7, 2009, p. 95.

20.MATASARU, D., SCARLATACHE, V.A., PRUTEANU, A., FLOREAN, B., VIZITEU, G., Proceedings Of The 2012 International Conference And Exposition On Electrical And Power Engineering, 2012, p. 116. .

21.MATASARU, P.D., IOP Conference Series: Materials Science and Engineering, 572, 2019, 012085.

22.BERE, P., DUDESCU, M.C., BALC, N., BERCE, P., IURIAN, A.M., NEMES, O., Mat. Plast., 67, no. 10, 2016, p. 2100.

24.SAVIN, C, NEJ NERU, C, PERJU, M.C., BEJ INARIU, C., BURDUHOSNERGIS, D., SANDU, A.V., Rev. Chim. (Bucharest), 70, no. 2, 2019, pp. 506.

25.BEJ INARIU, C, BURDUHOS-NERGIS, D.P., CIMPOESU, N., BERNEVIGSAVA, M. A., TOMA, S.L., DARABONT, D.C., BACIU C., Quality-Access to Success, 20, no. 1, 2019, pp. 71.

26.BEJINARIU, C., DARABONT, D.-C., BACIU, E.-R., GEORGESCU, I.S., BERNEVIG-SAVA, M.-A., BACIU, C., Sustainability, 9, 2017, p. 1263. 27.DARABONT, D.-C., MORARU, R.I., ANTONOV, A.E., BEJ INARIU, C., Quality-Access Success, 18, 2017, p. 11.

28.BEJ INARIU, C., DARABONT, D.C., BACIU, E.R., IONITA, I., SAVA, M.A.B., BACIU, C., Environmental Engineering Management J ournal, 16, 2017, p. 1395.

29.DARABONT, D.C., ANTONOV, A.E., BEJ INARIU, C., MATEC Web of Conferences, 121, 2017, UNSP 11007.

Manuscript received: 20.09 .2019 